\title{
NOTES ON FOREST INSECTS.
}

\section{NOTES ON SEVERAL SPECIES OF PITYOPHTHORUS BREEDING IN THE LIMBS AND TWIGS OF WHITE PINE.}

\author{
By M. W. Blackman Ph. D.
}

Professor of Forest Entomology, New York State College of Forestry, Syracuse, N.Y.

\section{Pityophthorus cariniceps LeConte.}

Pityopththorus cariniceps LeConte is one of the largest species of the genus Pityophthorus occurring in the eastern section of the country. It is found from Nova Scotia to West Virginia and westward as far as Michigan. For many years it has been known that it breeds in spruce (Hopkins, ${ }^{1}$ 1893, p. 208) and white pine (Chittenden, ${ }^{2}$ 1899) but it is still classed by Blatchley \& Leng ${ }^{3} 1916$ as "quite rare." In the vicinity of Syracuse this species could hardly be classed as rare, although it is not as common as are several other species of scolytids. There is one pine grove about one and onehalf miles from the college where the adults or brood can be found at any time during the spring or early summer breeding in the inner bark and sapwood of small limbs and twigs which have been storm-broken and have fallen to the ground during the previous winter.

On April 24, 1915, adults of $P$. cariniceps were observed starting their burrows in small storm-broken limbs and twigs of white pine in a dense pure stand of trees from 10 inches to 2 feet in diameter. The insects were working in limbs from $\frac{1}{4}$ inch to 1 inch in diameter and in nearly all instances the burrows were started near the axil of a smaller branch where the somewhat rough, folded outer bark furnished foothold for the little workers. Invariably it was the male which started the burrow. In a number of observed cases, groups of two or three beetles were found at these new burrows, the males working with part of their bodies in the recently started entrance gallery, while the others, which were

1 W. Va. Exper. Sta. Bull. 32.

2 U. S. Div. of Forestry Bull. 22.

3 Rhynchophora or Weevils of N. E. America, Indianapolis, 1916. 
females, lingered near and apparently took no farther part in the operations than occasionally to approach the working male and stroke him with their fore-legs and antennæ.

Some of the more advanced burrows opened at this time contained only a single male in the still uncompleted nuptial chamber, while in others the nuptial chamber was completed and occupied by the male and from one to three females. Some of these were preserved as specimens, while others were removed from their burrows and placed in jars with fresh pine limbs, into which the males immediately began burrowing. One of the new burrows thus started was examined nine days later (May 3) and was found to have three radiating egg-galleries containing eggs in the niches along each side. Several eggs, removed and preserved, were found to contain larvæ, the mandibles of which showed brown through the semi-transparent egg membranes. The remaining eggs - doubtless several days younger-when examined on May 6 were still unhatched, but on May 9, larvæ about one day old were found. On June 4, numerous apparently full grown larvæ and several pupæ were found although several of the parent adults were still alive in their egg-galleries.

Adults of the new generation emerged the following month during the writer's absence from the laboratory, and were numerous in the jars on his return July 2. It is thus apparent that several generations may occur during a single season and it seems probable that two broods per year are the rule in central New York. However, this depends very largely on the temperature and moisture conditions surrounding the particular branch in which the brood occurs. If this lies in a cool, shady spot where the sun never penetrates, the life processes are slowed up to such an extent that only one generation, or one and a half generations per year occur. In September, 1916, several branches, obtained where such conditions prevailed, contained young adults which from the character of their feeding burrows had fed as adults since midsummer. In other parts of the same woods, similar branches lying in places where the sun reached them during part of the day, had been long deserted by their brood and the feeding burrows showed that the young adults had remained in them a comparatively short time. The writer is certain that this difference is not entirely explained by the lengthened egg, larval and pupal periods, but that we have 
here to deal not only with the slowing up of the life processes of the insect in all of its stages, but also with a retarding influence which the relatively lower temperature and higher humidity seems to exert directly upon the young beetle, which prevents it from leaving its old host. These conditions simulate partially and in a milder way the climatic influences which in the fall prevent adults from emerging, although they are fully matured and will leave their old host in a few days if brought into the laboratory where they are under fairly warm and stable temperature conditions.

The brood burrows of $\boldsymbol{P}$. cariniceps are constructed in small limbs and twigs from $5 \mathrm{~mm}$. to $16 \mathrm{~mm}$. in diameter. They form rather coarse engravings and are excavated nearly entirely from the sapwood (Plate VII, fig. 1). The direction of the egg-galleries depends upon the diameter of the limb in which the insect works. In the smaller twigs they are necessarily mainly longitudinal, while in the larger material the direction is more likely to be diagonal. The nuptial chamber is rather large and very irregular, often with several short feeding galleries leading from it-probably made by the male-in addition to the true egg-galleries. The egg-galleries in the material at hand, vary in number from one to five to the engraving, with an average of three. They are wide and deep and vary in length from $5 \frac{1}{2} \mathrm{~mm}$. to $65 \mathrm{~mm}$. the average being about $24 \mathrm{~mm}$. The egg-niches are irregularly arranged on each side of the gallery and are excavated nearly entirely from the wood, although the larvæ at first feed chiefly upon the bark. In the material studied the average number of niches in an egggallery is about 10, but varies from 1 to 37 in the individual galleries.

The insects found most commonly associated with $P$. cariniceps are $P$. nudus Sw., $P$. granulatus Sw., $P$. puberulus Lec., Pitogenes hopkinsi Sw., and an undetermined Thripid. Of these P. puberulus and $P$. nudus were associated only in the smaller twigs, while Pityogenes hopkinsi occurred only in those more than $1 \mathrm{~cm}$. in diameter and here only rarely.

Pityophthorus canadensis Swaine.

Specimens of Pityophthorus canadensis Sw., which at the time were believed to be $P$. cariniceps, were taken by the writer on June 20, 1918, near Cranberry Lake in the Western Adirondack 
region of New York. On later examination these proved to belong to the closely allied species recently described by Swaine $\left(1917^{1}\right)$. The adults were obtained from storm-broken small branches of white pine and had but recently entered the bark at the axils of smaller twigs, where they were constructing their brood chambers. Usually one male and two or more females were obtained from each nuptial chamber. In a few cases the females had started egg-galleries and had deposited several eggs but most of the burrows were not so far advanced. As these beetles were believed to be $P$. cariniceps no observations on the latter stages of the brood burrows were made, but so far as observed, the breeding habits seem to agree very closely with the older species.

\section{Pityophthorus granulatus Swaine.}

The distribution of Pityophthorus granulatus Swaine is given by Swaine $^{2}$ as Manitoba, Quebec, and Nova Scotia, and the host trees as Jack Pine, White Pine and Balsam Fir. Specimens of this species in central New York breed very commonly in the thin barked region of white pine. They are most frequently found in the shaded-out limbs of larger pine trees and in the upper regions of small trees killed or dying by suppression. Small suppressed pines in the "red topped" condition are nearly sure to contain the brood of these small beetles and while they are occasionally found in broken limbs and in slash, they are much more characteristic of slowly dying limbs and tops. They breed by preference in thinbarked pine from 1 inch to 3 inches in diameter but are also found rather frequently in smaller limbs and twigs down to $\frac{1}{4}$ of an inch thick, in which material they are likely to be accompanied by P. nudus Sw.

The brood burrows of $P$. granulatus (Plate VIII, fig. 2, 3) differ considerably from those of $P$. cariniceps in several respects. They are, of course, much finer as would be expected from the smaller, more slender form of the beetles making them, but the most striking differences have to do with the larger number of egg-galleries in each engraving and the extraordinary length of these egg-galleries.

The nuptial chamber is often very small-so small that in many cases it seems to be merely the meeting point of a number of egg-

1 Dom. Can., Ent. Br., Dept. Agr., Bull. 14, p. 24, 25.

${ }^{2}$ Dom. Can., Ent. Br., Dept. Agri., Bull. 14, p. 106. 
galleries. It varies from $2 \mathrm{~mm}$. to $4 \mathrm{~mm}$. in diameter and is usually by no means large enough to accommodate all of the inhabitants of the burrow at one time. Radiating from this nuptial chamber are from three to nine egg-galleries, each made by a different female. These lie nearly entirely in the sapwood grooving this deeply and scoring the inner bark only slightly. Where the egggalleries are numerous they start from the nuptial chamber in all directions, often being nearly symmetrical in their arrangement near their origin (Plate VIII, fig. 2), when the engravings are in the larger limbs or tops. However, those galleries which start transversely or diagonally to the grain of the wood, soon curve and are continued in a general longitudinal direction.

As has been stated, the egg-galleries vary in number from three to nine and in the material studied there was an average of nearly six (5.7) to the engraving. With such a great preponderance of females it might be expected that they would show a decrease in fecundity as compared with other bark beetles. Yet such is not entirely true for in 58 egg-galleries studied, the average number of egg-niches is 28, as compared with 19.05 in Ips. longidens ${ }^{1}$ Sw., 19.89 in Pityogenes hopkinsi ${ }^{2}$ Sw., 20.84 in Polygraphus rufipennis ${ }^{3}$ Kirby and 30.65 in Eccoptogaster picea ${ }^{4}$ Sw. But the most extraordinary characteristic of the engravings of these little beetles is the length of the egg-galleries. A study of a number of engravings shows that these galleries made by the females vary in length from $6 \mathrm{~mm}$. to $250 \mathrm{~mm}$. (10 inches), with an average of 89.6 $\mathrm{mm}$. for sixty-two egg-galleries. When the small size $(1.6 \mathrm{~mm}$. long) of the beetles is taken into consideration, it is seen that the female whose egg-gallery is 10 inches long (Plate VIII, fig. 3) had actually mined through the sapwood for a distance equal to $\mathbf{1 5 6}$ times her own length. The extraordinary length of these galleries is also brought out by comparing their average length of $\mathbf{8 9 . 6}$ $\mathrm{mm}$. with those of $P$. hopkinsi ${ }^{5}$ (23.1 mm.), P. rufipennis ${ }^{5}$ (24.55 $\mathrm{mm}$.), E. picee $e^{5}$ (27.36 mm.) and L. longidens ${ }^{5}(18.8 \mathrm{~mm}$.).

The egg-galleries of $P$. granulatus differ from those of most scolytids also in that they are not kept free of frass, but with the

1 Blackman, 1919, Psyche, Vol. 26, p. 88.

2 Blackman, 1915, N. Y. S. Coll. Forestry, Tech. Pub. No. 2, p. 50.

3 Blackman and Stage, 1918, N. Y. S. Coll. Forestry, Tech. Pub. No. 10, p. 45.

4 Op. cit., p. 53.

$\checkmark$ Loc. cit. 
exception of the first few millimeters, are packed full of the detritus derived from the excavation of the burrow. This doubtless is correlated with their unusual length. The egg-niches are spaced at considerably wider intervals than is common with other scolytids, seldom being closer together than $4 \mathrm{~mm}$. and often being considerably farther apart. This is especially noticeable in the terminal portions of the longer burrows. It would seem that the female beetle continues to extend her burrows at about the same rate even after her egg laying is nearly or quite completed.

While absolute proof is not at hand, the evidence indicates that in the latitude of central New York there is but one generation of $P$. granulatus each year. It is doubtful if this insect is ever injurious. Usually, indeed, it should in my opinion be classed as beneficial from the standpoint of forestry, for by preference it attacks trees or limbs which are dying from suppression. In attacking dying suppressed trees, it hastens but little the death of trees which would inevitably soon be lost in any event. On the other hand, in attacking suppressed limbs, it completes the death of these and thus confers a benefit by hastening the natural pruning necessary for the production of good, clear timber.

Insects found associated with $P$. granulatus in white pine include Chrysobothris femorata Fabr., C. dentipes Germ., Pogonocherus mixtus Hald., Leptostylus sexguttatus Say., Pityogenes hopkinsi Sw., Pityophthorus nudus Sw., P. cariniceps Lec., P. puberulus Lec., and the predators, Phyllobanus dislocatus Say and Hypophlous tenuis Lec. Cocoons of a small hymenopterous parasite have been found at the ends of the larval burrows but the writer has not succeeded in breeding these out.

Pityophthorus nudus Swaine.

Pityophthorus nudus Sw. is found in Quebec, Ontario and New York, and breeds in white spruce, Picea canadensis (Swaine, 1917, p. 30). It is very similar to $P$. granulatus not only in structure but also in habits. The writer has observed it in central New York breeding in small limbs of white pine where it is usually associated with granulatus, although it is here by no means as common as the latter. All our specimens of this species were obtained from limbs less than one-half inch in diameter, although it may occur in larger limbs and tops as well. The engravings made by the insects in 
breeding are very similar to those of $P$. granulatus, the chief difference being in the shorter egg-galleries apparently characteristic of $P$. nudus.

Insects derived from the same material and associated with $P$. nudus include $P$. granulatus Sw., $P$. cariniceps Lec., $P$. puberulus Lec., Pityogenes hopkinsi Sw. and the clerid Phyllobronus dislocatus Say.

Pityophthorus puberulus LeConte.

Pityophthorus puberulus Lec. is apparently distributed over the eastern portions of the United States and Canada and according to Swaine 1918 (loc. cit.) breeds in pine and balsam fir. The writer has found it in central New York only a few times but whenever found it always seemed to occur in immense numbers. The beetles attack the terminal twigs and smallest limbs of diseased or dying white pine branches. Occasionally it also attacks healthy terminal twigs as well, but seems to prefer most of all the twigs of branches freshly broken from the trees.

The adults bore through the bark of the smallest twigs at the bases of the pine needles and eat not only the inner bark but also a considerable part of the wood (Plate IX, fig. 4, b, c, d, e, f). They often penetrate into the center of the twig and sometimes continue their feeding burrow in the pith for some distance. These burrows in the smallest terminal twigs are primarily feeding burrows, although not entirely so.

One peculiarity in the feeding of $\boldsymbol{P}$. puberulus is their apparent fondness for pitch. As a rule scolytids, even species which have demonstrated their ability to live in burrows flooded with pitch, and to dispose of this by the construction of pitch-tubes, avoid pitchpockets and pitch-sinuses when possible. $P$. puberulus, however, shows no such avoidance of the numerous pitch sinuses, which extend longitudinally in the inner part of the more or less abnormal bark of diseased or broken limbs. On the contrary, when the burrowing beetle taps one of these sinuses, it seems nearly invariably to continue its mine along the course of the cavity. This species seems to have solved the question of manipulating the pitch not by removing it from its burrow and building it up around the entrance in the form of a pitch-tube, but to a great extent at least by eating it. When a pitch-sinus is tapped and the pitch begins to flow into the 
insect's burrow, the beetle prevents the burrow from being flooded by partially plugging the opening into the pitch-sinus with bits of sawdustlike frass. The pitch-soaked frass is apparently used as food and that eaten is replaced with new bits of "saw-dust." This is continued until most of the more liquid pitch is drained from the sinus and then the sawdust plug is eaten away and the burrow continued along the pitch cavity. The foregoing is based on direct observation made with a binocular miscroscope.

The beetles breed not only in the terminal twigs (Plate IX, fig. $4, \mathrm{~b}, \mathrm{c}, \mathrm{d}, \mathrm{e}, \mathrm{f})$, but also in the larger twigs from $4 \mathrm{~mm}$. to $8 \mathrm{~mm}$. in diameter (Plate IX, fig. 4, a). They nearly invariably enter at the axil of a smaller twig, constructing the nuptial chamber either on the surface of the wood or in the inner bark, depending upon the thickness of the latter. In the material at hand the egg-galleries are short and irregular both in diameter and in direction. In many cases the eggs are laid in piles or groups, and lie unprotected in one corner of the nuptial chamber or in a wide alcove extending from it. In still other instances the egg tunnels extend through the axis of the twig in the pith and the larvæ arising from the egg niches in the walls of the tunnel bore directly through the soft sapwood to the inner bark surrounding it, where they continue their burrows. The larval mines are broad and irregular and often coalesce so that it is not unusual, on removing the outer bark of larger twigs, to find a number of larvæ working in a common chamber excavated by their joint efforts. However, before pupating, each larva in such instances, constructs a short individual burrow ending in a pupation chamber. The larvæ also seem to eat pitch, as their burrows often involve pitch-sinuses and, indeed, individual burrows frequently follow one of the pitch-sinuses for some distance.

As regards the economic importance of $P$. puberulus, it will be seen at once that insects which possess to such a marked degree the ability to live in pitch, have the power to do considerable damage. However, according to the writer's observations, these minute beetles only occasionally attack perfectly healthy twigs. They seem much to prefer the twigs of freshly broken limbs, or of limbs which are undergoing suppression by shading, or which are unhealthy from other causes. Apparently, then, they are only occasionally injurious, and from the point of view of the forester, are perhaps as often beneficial in hastening natural pruning, and 
thus aiding in the production of clear timber. The rôle they play in hastening the reduction of broken twigs and limbs to humus is also mildly beneficial.

Pityophthorus cariniceps Lec. and Pityogenes hopkinsi Sw. are often associated with Pityophthorus puberulus in storm-broken limbs of white pine, while Pityophthorus granulatus Sw. and $\boldsymbol{P}$. $n u d u s$ Sw. frequently occur in the same suppressed pine limbs, and the work of all three combine in aiding in the death of such parts and thus hastening natural pruning. Other insects occurring in the larger portions of suppressed limbs, include Chrysobothris dentipes Germ., C. femorata Fabr., Pogonocherus mixtis Hald., and Leptostylus sexguttatus Say.

\section{Explanation of Plates.}

\section{Plate VII.}

Fig. 1. Brood burrows of Pityophthorus cariniceps in small storm-broken limbs of white pine. Note the coarse egg-galleries grooving the sapwood deeply and containing relatively few eggniches. About four-fifths natural size.

\section{Plate VIII.}

Fig. 2. Section of upper trunk of a small suppressed white pine showing the characteristic engravings made by Pityophthorus granulatus. Note the long fine egg-galleries with rather sparsely placed egg-niches from which the larval mines originate. The brood burrow originating in the center has 7 egg-galleries while that near the bottom has 9. About five-sixths natural size.

Fig. 3. Two adjacent pieces of a smaller limb showing brood burrow of $P$. granulatus having 6 egg-galleries. One of these marked " $a$ " reaches a length of $250 \mathrm{~mm}$. (10 inches). About four-fifths natural size.

\section{Plate IX.}

Fig. 4. Brood burrows and feeding burrows of Pityophthorus puberulus. " $A$ " brood burrows in small limb $6 \mathrm{~mm}$. in diameter; $b, c, d$, e, and $\mathrm{f}$ burrows in the smallest leaf bearing twigs of white pine. All magnified about $2 \frac{1}{2}$ diameters. 


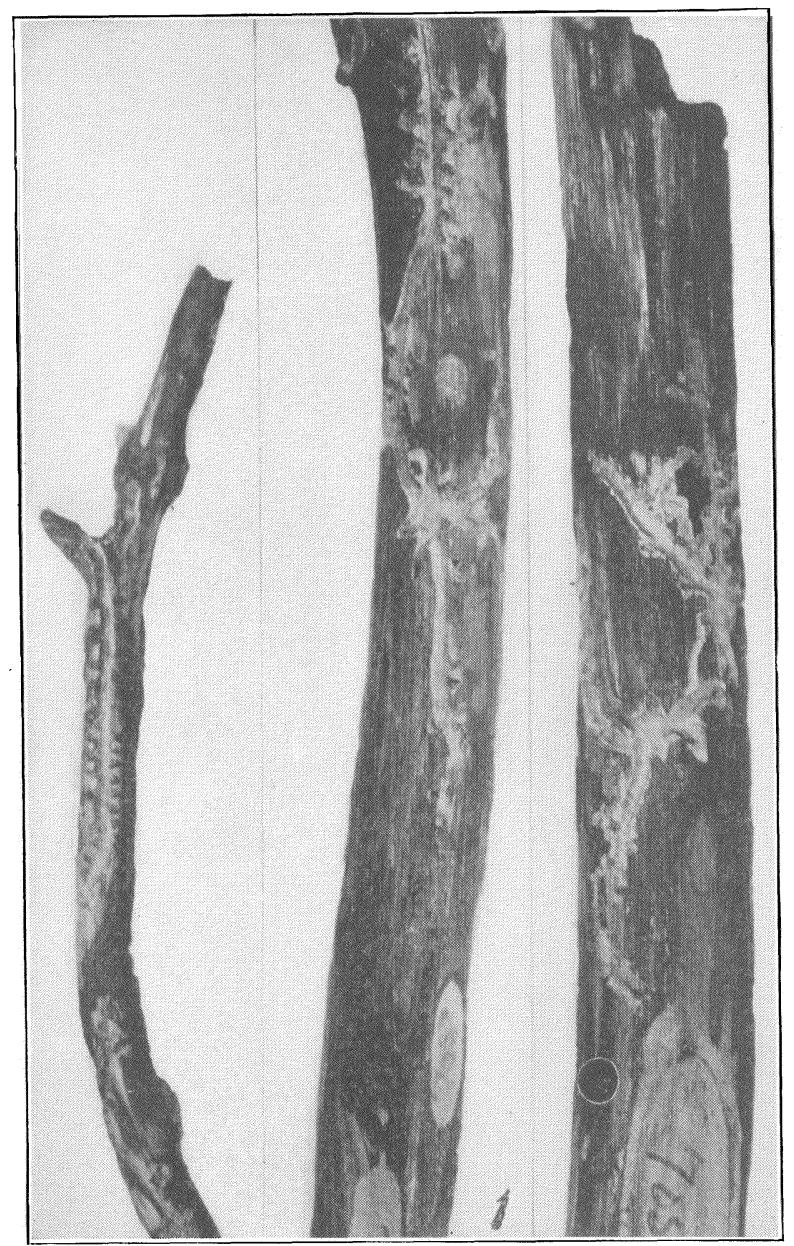

BLACKMAN-Forest InseCts. 


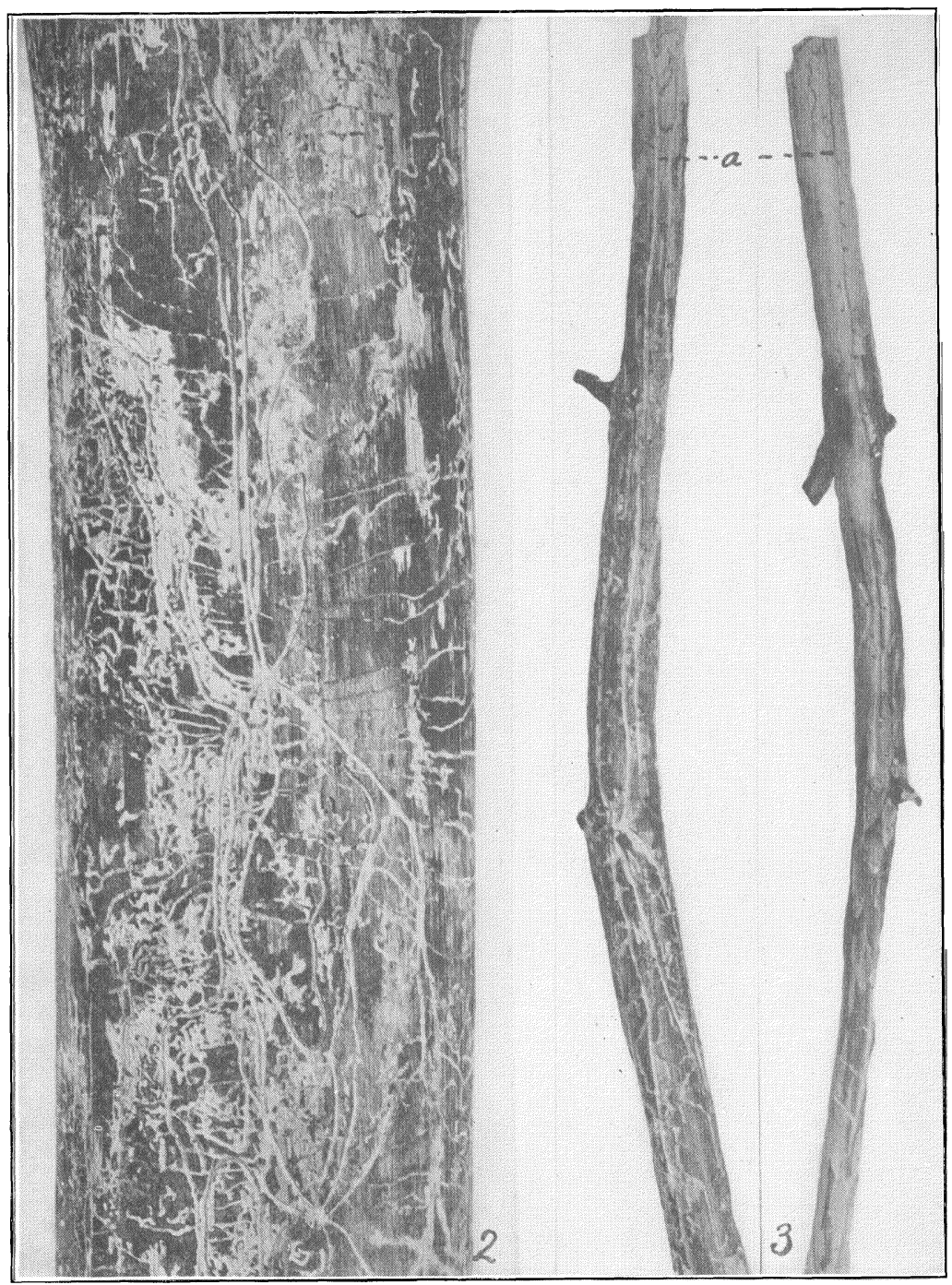

Blackman-Forest Insects. 
Psyche, 1919.

Vol. XXVI, Plate IX.

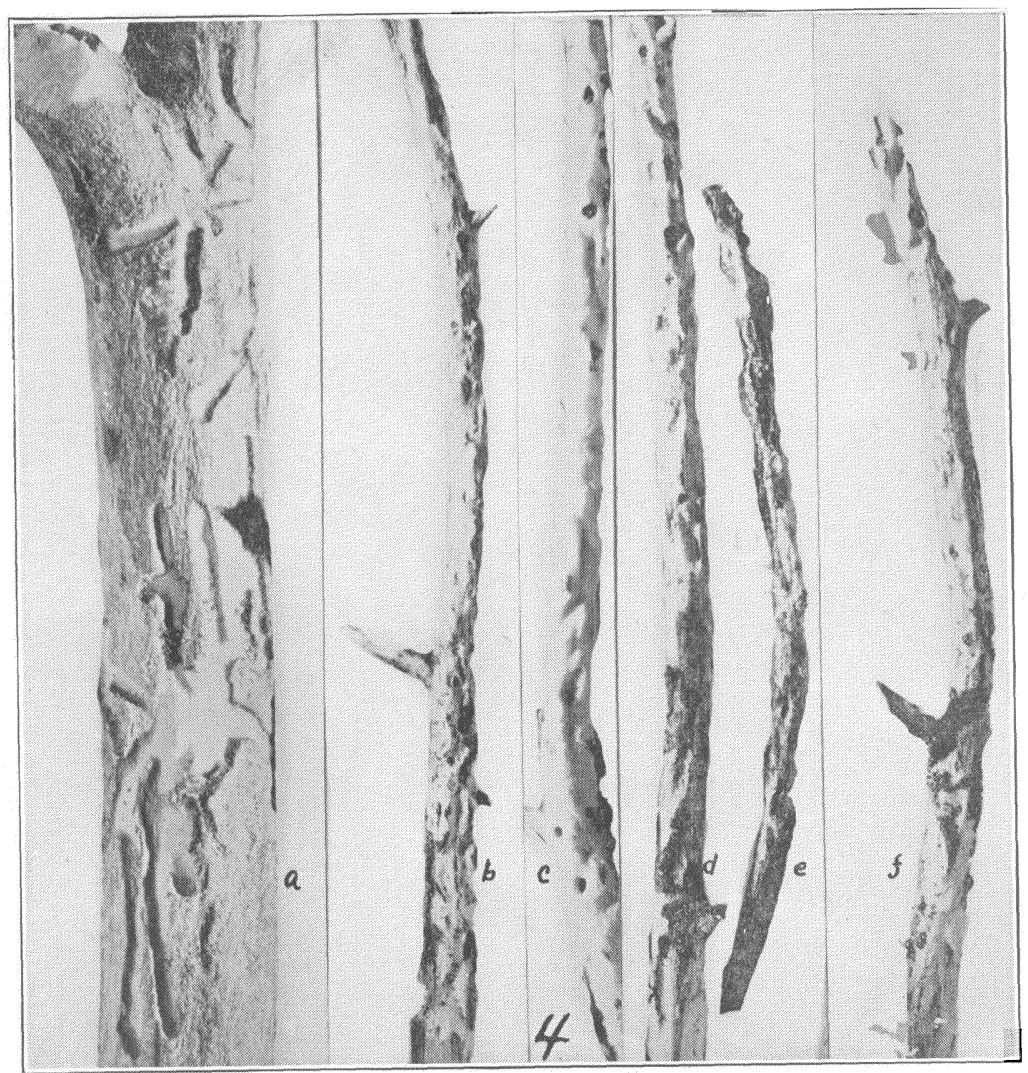

Blackman--Forest Insects. 

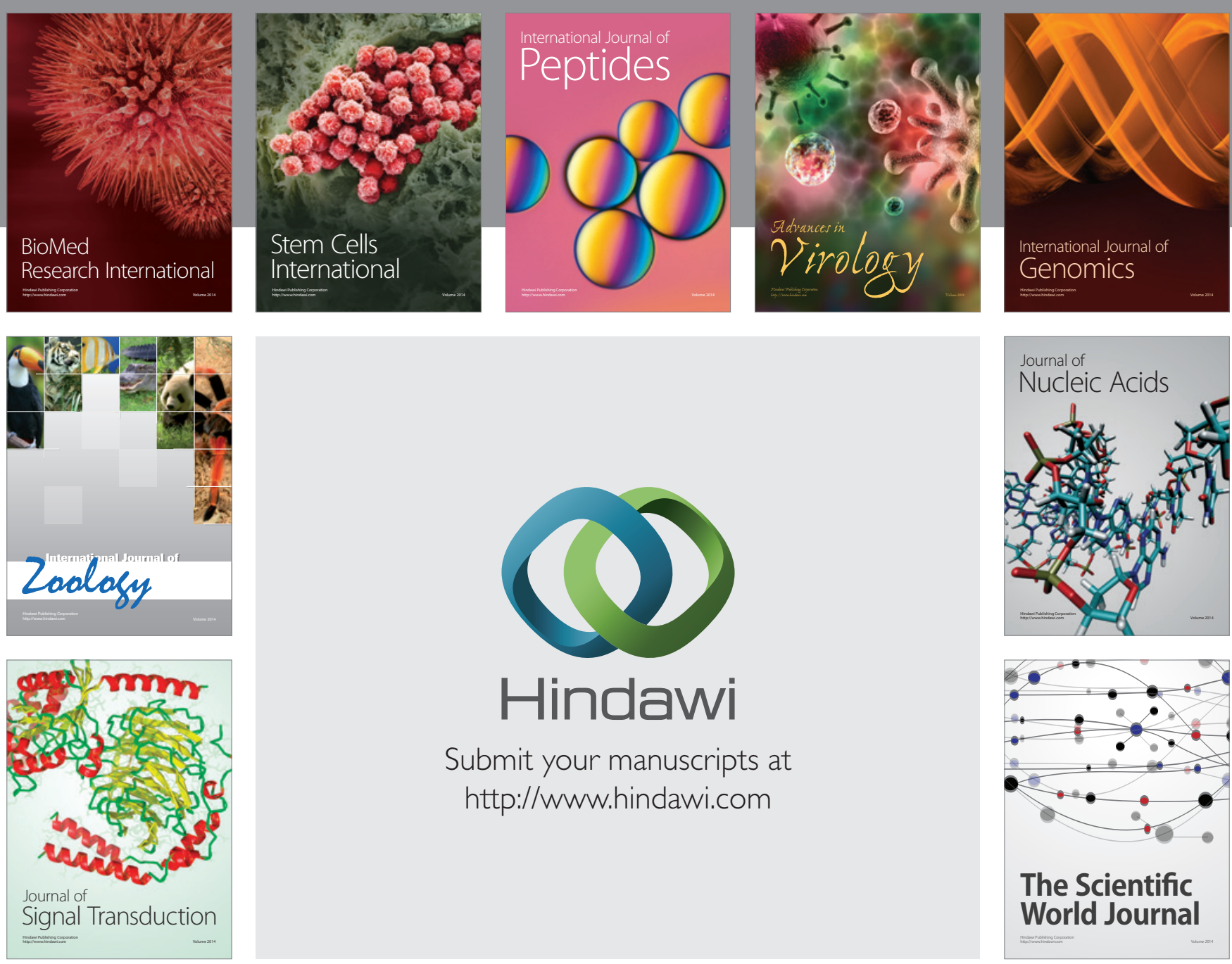

Submit your manuscripts at

http://www.hindawi.com
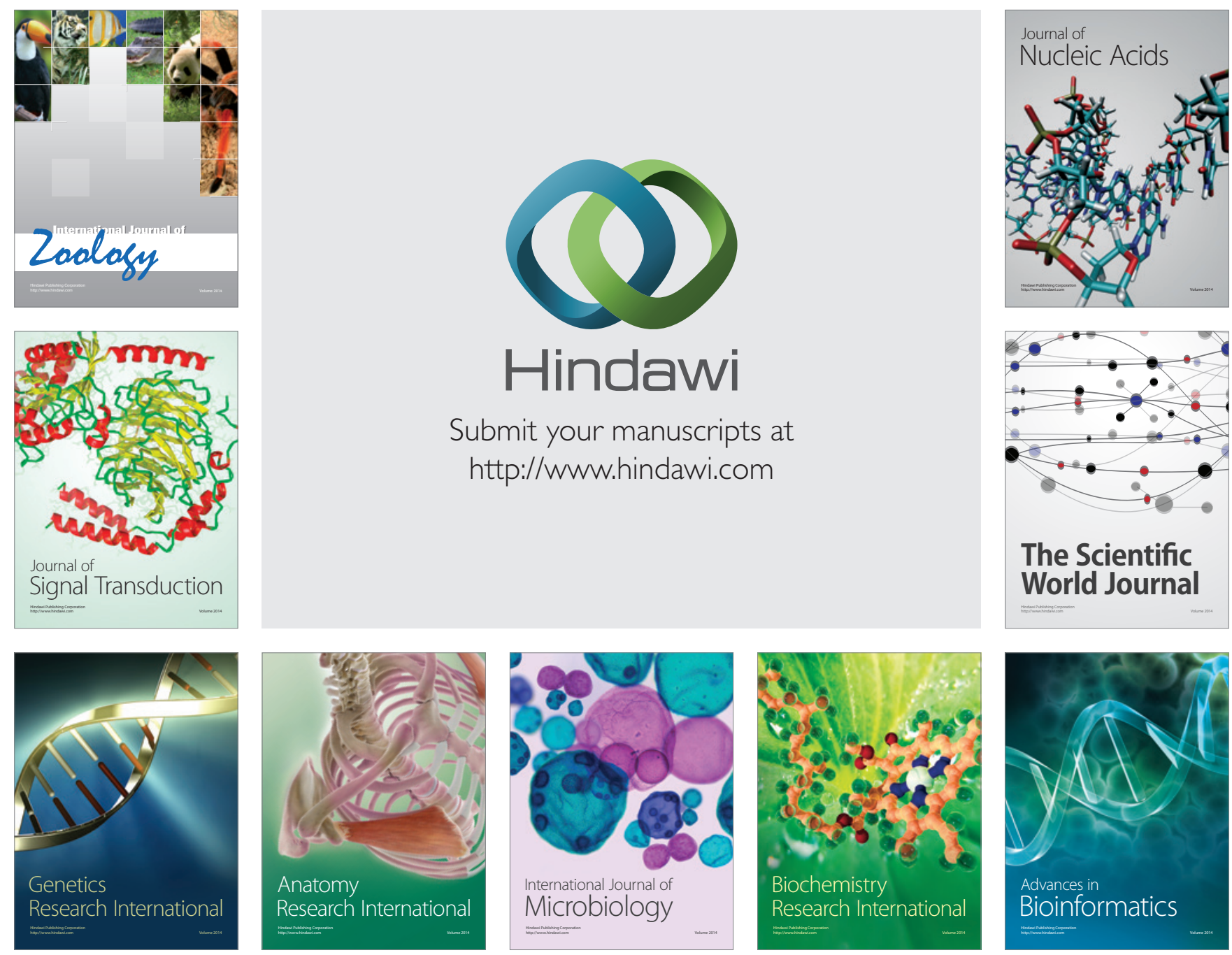

The Scientific World Journal
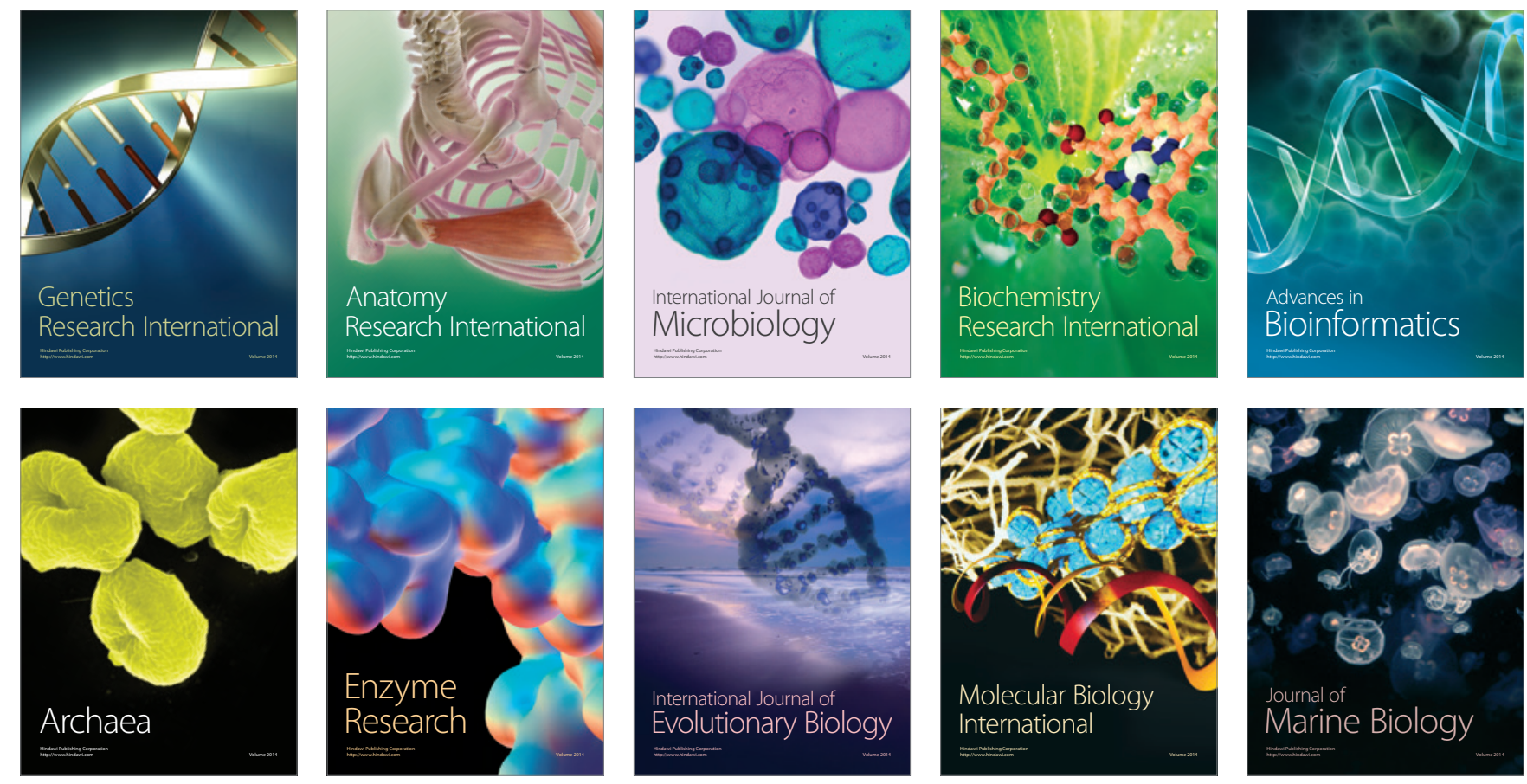